\title{
Feasibility Study of the Use of Concrete Sludge As Alternative Raw Material for Portland Clinker Production
}

\author{
Joris Schoon ${ }^{1}$; Klaartje De Buysser²; Isabel Van Driessche ${ }^{3}$; and Nele De Belie ${ }^{4}$
}

\begin{abstract}
This study aims to examine the use of concrete sludge from water treatment installations of ready-mixed concrete plants as an alternative raw material for portland clinker kilns, and to enumerate possible limitations. By its extensive and representative collection of concrete sludge samples data, it may also be used for other investigations. The chemical variations of this sludge were evaluated by gathering 87 sludge samples over a period of two years. Furthermore, a treatment phase was proposed. Numerical simulations were conducted based on the chemistry of a representative concrete sludge sample, before and after a specific treatment phase, together with classic raw materials of three reference clinker factories to investigate the influence of the sludge on the clinker meal composition. Based on these simulations, experimental clinkers were produced, which were fully analyzed and evaluated for possible mineralogical influences. Based on the findings of this investigation, it was concluded that sludge out of concrete plants could not be classified as a feasible alternative raw material. Nevertheless, this paper has unveiled some attention points for the use of recycled materials or by-products as alternative raw materials for portland clinker production. DOI: 10.1061/(ASCE)MT.1943-5533.0001230. ㅇ 2014 American Society of Civil Engineers.
\end{abstract}

Author keywords: Clinker; Concrete sludge; Water treatment installation; Fines; Sulfur trioxide.

\section{Introduction}

The production and transport of ready-mixed concrete necessitate the recuperation of sludge water that is too contaminated with concrete residuals to be discharged into sewerage. This sludge water is generated by washing of the ready-mixed concrete and transport equipment during daily maintenance. Prior to the disposal of sludge water from the ready-mixed concrete plants, a pretreatment in two sedimentation basins is required. The first basin receives the sludge water from the mixer trucks. The water fraction, with some limited sediment fraction, is transferred to a second basin. After sedimentation, water from both basins is recycled and the sludge in the first and the second basins is removed. Globally, the sludge is disposed as landfill, which has an ecological impact and a financial disadvantage in terms of disposal costs in accordance of its Eural-code (101314) (Ökopol GmbH et al. 2008). Therefore, the valorization of this sludge of concrete plant (SCP) is a key concern in the production of ready-mixed concrete and the reason for this feasibility study. Several studies have already examined the recuperation of

${ }^{1}$ S.A. Sagrex N.V., Heidelberg Cement Benelux, Heidelberg Cement Group, Terhulpsesteenweg 185, B-1170 Brussels, Belgium (corresponding author). E-mail: joris.schoon@gmail.com

${ }^{2}$ Professor, Faculty of Sciences, Sol Gel Centre for Research on Inorganic Powder and Thin Film Synthesis (SCRiPTS), Dept. of Inorganic and Physical Chemistry, Ghent Univ., Krijgslaan 281-S3, B-9000 Ghent, Belgium.

${ }^{3}$ Professor, Faculty of Sciences, Sol Gel Centre for Research on Inorganic Powder and Thin Film Synthesis (SCRiPTS), Dept. of Inorganic and Physical Chemistry, Ghent Univ., Krijgslaan 281-S3, B-9000 Ghent, Belgium.

${ }^{4}$ Professor, Faculty of Engineering and Architecture, Magnel Laboratory for Concrete Research, Dept. of Structural Engineering, Ghent Univ., Technologiepark Zwijnaarde 904, B-9052 Ghent, Belgium. E-mail: nele .debelie@UGent.be

Note. This manuscript was submitted on April 29, 2014; approved on October 29, 2014; published online on December 24, 2014. Discussion period open until May 24, 2015; separate discussions must be submitted for individual papers. This paper is part of the Journal of Materials in Civil Engineering, (C) ASCE, ISSN 0899-1561/04014272(12)/\$25.00. different types of sludge and sludge water in fresh concrete, which demonstrated its negative impact on compressive strength and setting time, workability, and water demand (Chatveera et al. 2006; Sales et al. 2011; Chatveera and Lertwattanaruk 2009; Lin et al. 2005; Tay 1989; Lin and Lin 2005).

This paper investigates the valorization of the sludge fraction as an alternative raw material (ARM) for portland clinker production, based on an extensive and representative collection of concrete sludge sample data. The study includes a batch of 87 sludge samples from the first basin, which were collected over a period of two years to ensure a realistic evaluation. The collected samples of the dried sludge were analyzed for their chemical composition and variations, and for their physical properties. These parameters are important because they influence the feasibility of using the dry sludge as ARM (Schoon et al. 2012, 2013a, b, unpublished data, 2014). The chemical and mineralogical composition of sludge is primarily influenced by the raw materials used for the production of ready-mixed concrete. The water fraction according to $N B N E N$ 1008 [Bureau of Normalization (NBN 2002)] can be reused in the ready-mix concrete production process, during which a fraction of small sediments in the water is allowed.

\section{Materials and Methods}

\section{Classic Raw Materials}

The materials used on a daily basis in three modern clinker factories are selected as representative classic raw material (CRM). These factories are CBR Antoing (Ant) and CBR Lixhe (Lxh) in Belgium, and ENCI Maastricht (Maa) in the Netherlands, all belonging to the Heidelberg Benelux group. They can be considered as representative for modern clinker factories worldwide. CBR Antoing uses rich and poor limestone, CBR Lixhe uses tufa and loam, and ENCI Maastricht uses a typical marl and sabulous clay to deliver the required $\mathrm{CaO}$ and $\mathrm{SiO}_{2}$. All three factories use fly ash as the source of $\mathrm{Al}_{2} \mathrm{O}_{3}$ and an artificially produced $\mathrm{Fe}_{2} \mathrm{O}_{3}$ source. These CRMs have been described in detail (Schoon et al. 2012) 
Table 1. Average Chemical Analysis of the Limestones and $\mathrm{SiO}_{2}$ Sources of CBR Antoing, CBR Lixhe, and ENCI Maastricht

\begin{tabular}{|c|c|c|c|c|c|c|c|}
\hline CRM & Unit & Poor limestone & Rich limestone & Tufa & Loam & Marl & Sabulous clay \\
\hline $\mathrm{CaO}$ & $\%$ by weight & 42.9 & 50.1 & 51.8 & 5.6 & 50.8 & 2.66 \\
\hline $\mathrm{SiO}_{2}$ & $\%$ by weight & 15.1 & 6.4 & 4.7 & 68.9 & 7.1 & 86.83 \\
\hline $\mathrm{Al}_{2} \mathrm{O}_{3}$ & $\%$ by weight & 2.2 & 0.9 & 0.4 & 7.4 & 0.8 & 3.73 \\
\hline $\mathrm{Fe}_{2} \mathrm{O}_{3}$ & $\%$ by weight & 0.9 & 0.4 & 0.3 & 3.8 & 0.4 & 2.58 \\
\hline $\mathrm{K}_{2} \mathrm{O}$ & $\%$ by weight & 0.68 & 0.21 & 0.07 & 1.68 & 0.13 & 1.14 \\
\hline $\mathrm{Na}_{2} \mathrm{O}$ & $\%$ by weight & 0.25 & 0.25 & 0.02 & 0.71 & 0.20 & 0.14 \\
\hline $\mathrm{SO}_{3}$ & $\%$ by weight & 0.90 & 0.57 & 0.09 & 0.06 & 0.21 & 0.05 \\
\hline $\mathrm{MgO}$ & $\%$ by weight & 1.1 & 0.9 & 0.7 & 0.8 & 0.8 & 0.28 \\
\hline $\mathrm{Cl}$ & $\%$ by weight & - & - & 0.011 & - & - & 0.01 \\
\hline LOI $975^{\circ} \mathrm{C}\left(\mathrm{O}_{2}\right)$ & $\%$ by weight & 35.04 & 40.18 & 42.03 & 10.1 & 40.18 & 3.43 \\
\hline
\end{tabular}

and used in other investigations (Schoon et al. 2012, 2013a, b). The chemical analyses of the corresponding CRMs are presented in Table 1.

\section{Alternative Raw Material: Recycled Concrete Sludge}

A first batch of SCP was collected from 20 ready-mixed concrete plants of Inter Beton (IB), belonging to the Heidelberg Benelux group. This collection was necessary to have an initial idea of the chemical variation of the sludge. From this first batch, five readymixed concrete plants were selected according to their geographic position, mutual variation in origin of aggregates (Ag), and the widest possible chemical variation, based on the chemical analyses of the first batch of sludge samples (Fig. 1). IB Genk was selected because the sample from the first batch had the lowest $\mathrm{CaO}(\%$ by weight) and the highest $\mathrm{SiO}_{2}$ (\% by weight). Additionally, its geographical position in the north-east of Belgium allows IB Genk to partially use river gravel. IB Brussel was chosen because its sample from the first batch had the lowest $\mathrm{SiO}_{2}$ (\% by weight) and it is located in the center of Belgium. Furthermore, IB Brussel regularly works with porphyry material (Schoon et al. 2013b). IB VillersLe-Bouillet was used as backup for IB Brussel, as the second lowest in $\mathrm{SiO}_{2}$ (\% by weight), because it was communicated that adaptions to the water treatment installation were planned, so sampling during a certain time was not possible. Another reason was that this plant is located in the east of Belgium and works with dolomitic limestone, which is found locally in the region of Namur (Schoon et al. 2013b). IB Zeebrugge was chosen because it had a similar amount of average $\mathrm{SiO}_{2}(\%$ by weight) in the first batch. This plant uses sea gravel for concrete production, because it is located in the west of Belgium, close to the sea. IB Dendermonde was selected because it has the newest and most modern water treatment installation within the IB group. Just like IB Brussel, IB Dendermonde is located in the center of Belgium and works with a wide variety of aggregates, such as porphyry, limestone, and sea material.

To create a representative batch of sludge samples, a sample was taken each month from the plants of IB Zeebrugge and IB Dendermonde. This made it possible to investigate, if present, the influence of the seasons on the chemical composition of the sludge. The chemical composition could be altered during winter by the increased use of portland cement and during summer by the increased use of slag cement, which are often used in Belgium and the Netherlands. From the plants of IB Brussels, IB Genk, and IB Villers-le-Bouillet, samples were collected every three months. After its water treatment installation was revamped, sampling of IB Brussels was collected each month. This made a total of another

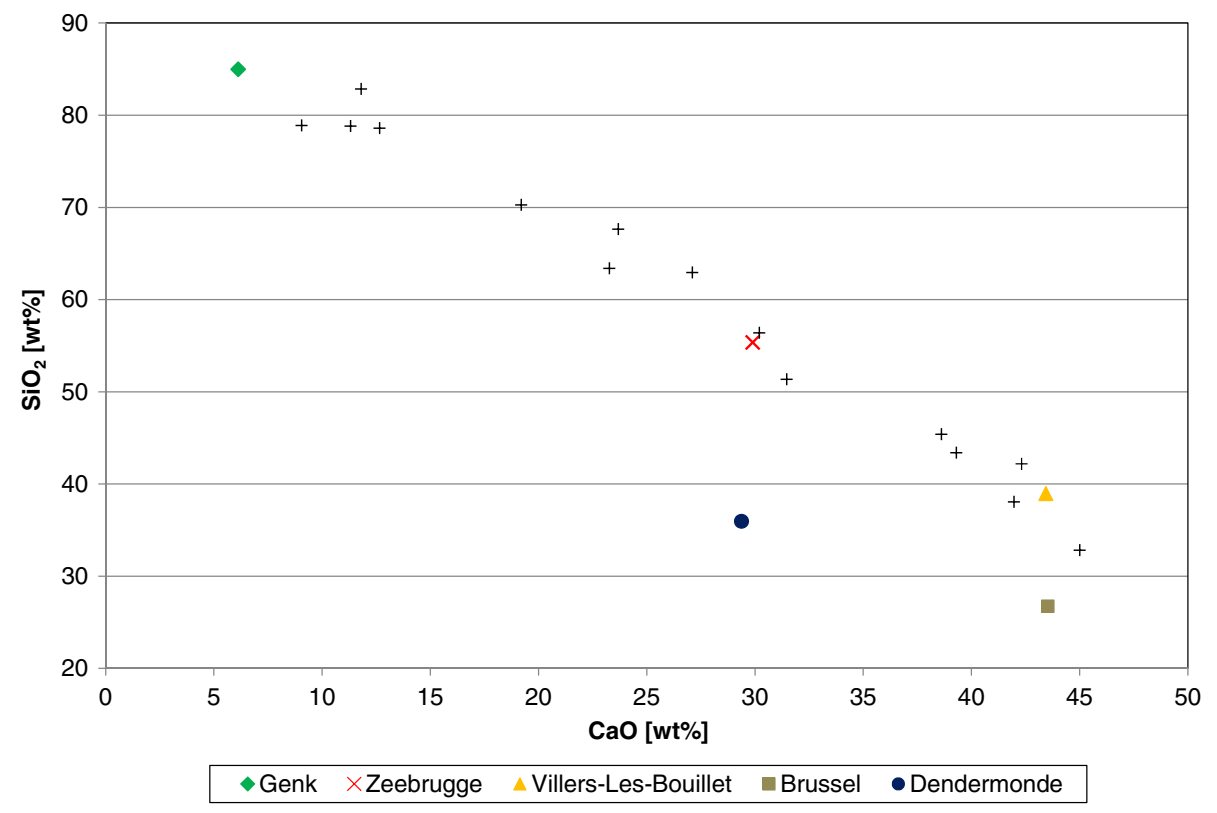

Fig. 1. $\mathrm{CaO}(\%$ by weight $)$ as function of $\mathrm{SiO}_{2}(\%$ by weight $)$ without LOI. for the first 20 batch sludge samples 
67 concrete sludge samples in a second batch. Together with the first batch, 87 sludge samples were collected over a period of two years.

\section{Testing of Raw Materials; Cold Clinker Meals; Clinker and Cement Properties}

The procedure to recover the sludge material from the basin was to shovel the concrete sludge with the bucket of a wheel loader $\left( \pm 2 \mathrm{~m}^{3}\right)$, deposit the material on a flat floor, and leave it to allow the water to drain away. After $1 \mathrm{~h}$, a sample $(5 \mathrm{~L})$ was collected from the middle of the heap and transferred to a bucket. Each month, the different sludge samples of the concrete plants were collected and shipped to the lab, after which they were dried for two days at $120^{\circ} \mathrm{C} \pm 1$ and crushed to \pm 4 -mm-sized particles in a jaw crusher (Retsch, Haan, Germany) to simulate a realistic crushing action. Five hundred grams were taken from the homogenized sludge sample and further prepared for chemical analysis. The rest of the crushed material was collected to determine the particle size distribution (PSD) by using a sieve tower from $63 \mu \mathrm{m}$ up to $16 \mathrm{~mm}$ according to NBN EN 1097-6 (NBN 2000). From the 87 collected concrete sludge samples, 15 samples were selected for determination of PSD. The PSD of the fines fraction collected after the passing the $250-\mu \mathrm{m}$ sieve was further determined by Sympatec laser diffraction. These 15 samples were chosen by selecting three sludge samples of each of the five concrete plants, assuring satisfactory representation in the sludge samples collected from the five selected concrete plants (Fig. 2). To investigate the effect of a separation phase on the sludge samples already shown as prosperous for production of recycled concrete aggregates as a function of their ARM fitness (Schoon et al., unpublished data, 2014), these 15 samples were recovered after PSD measurement in three fractions: a fines fraction smaller than $250 \mu \mathrm{m}$, a fraction between 250 and $500 \mu \mathrm{m}$, and a fraction larger than $500 \mu \mathrm{m}$. Finally, from these 15 selected samples, the sludge sample marked as "SCP/Avg" (Avg = average) in Fig. 2 was chosen, having $\mathrm{SiO}_{2}$ (\% by weight) and $\mathrm{CaO}$ (\% by weight) near the average of all 87 collected sludge samples. The samples and separated fractions selected for chemical analysis were prepared by grinding for $2 \mathrm{~min}$ in a vibratory disc mill. X-ray fluorescence (XRF) analysis was performed on a Philips PW2404 and the total carbon $(\mathrm{C})$ and sulfur (S) contents were determined by using a Leco CS230. Thermogravimetric analysis (TGA) and differential thermal analysis (DTA) was performed on a Netzsch STA 449F3. TGA analyses were performed on the separation fractions and the sludge sample itself of five concrete sludge samples individually taken from each of the five concrete plants. They were selected to be most similar to the average chemical composition of their proper concrete plant (Fig. 2) and already present in the collection of the 15 selected concrete sludge samples. SCP/Avg and its fines fraction smaller than $250 \mu \mathrm{m}$ (Fines/Avg) were individually used to make numerical simulations in addition to artificial clinkers for each clinker factory. The different cold clinker meal (CCM) compositions were all prepared as described by Schoon et al. (2012). All raw materials were crushed in a Siebtechnic Disc mill and homogenized in a vessel used for analysis of micro-Deval abrasion resistance, after which they were further ground for $10 \mathrm{~min}$ at $300 \mathrm{rpm}$ in a laboratory ball mill. All CCM were, after a granulation phase, sintered in an electric high-temperature static kiln (Carbolite BLF1800) up to $1,450^{\circ} \mathrm{C}$ at a constant heating rate $\left(10^{\circ} \mathrm{C} / \mathrm{min}\right)$. The hot clinker meals $(\mathrm{HCMs})$ were maintained at the scheduled temperature for $1 \mathrm{~h}$ after which they were quenched to room temperature to form the final clinker. X-ray diffraction (XRD) analysis, refined by the Rietveld method (TOPAS software), was performed on a Bruker D8 ADVANCE. All of these analysis methods have been used and described in more detail in other research papers (Schoon et al. 2012, 2013a, b, unpublished data, 2014).

\section{Theory/Calculation}

\section{Chemical and Mineralogical Limitations of Reference Clinkers and Clinker Kiln}

Realistically simulated clinker production at lab scale is quite difficult because of the specific construction of a clinker kiln. Therefore, limitations have to be defined that may prevent undesirable

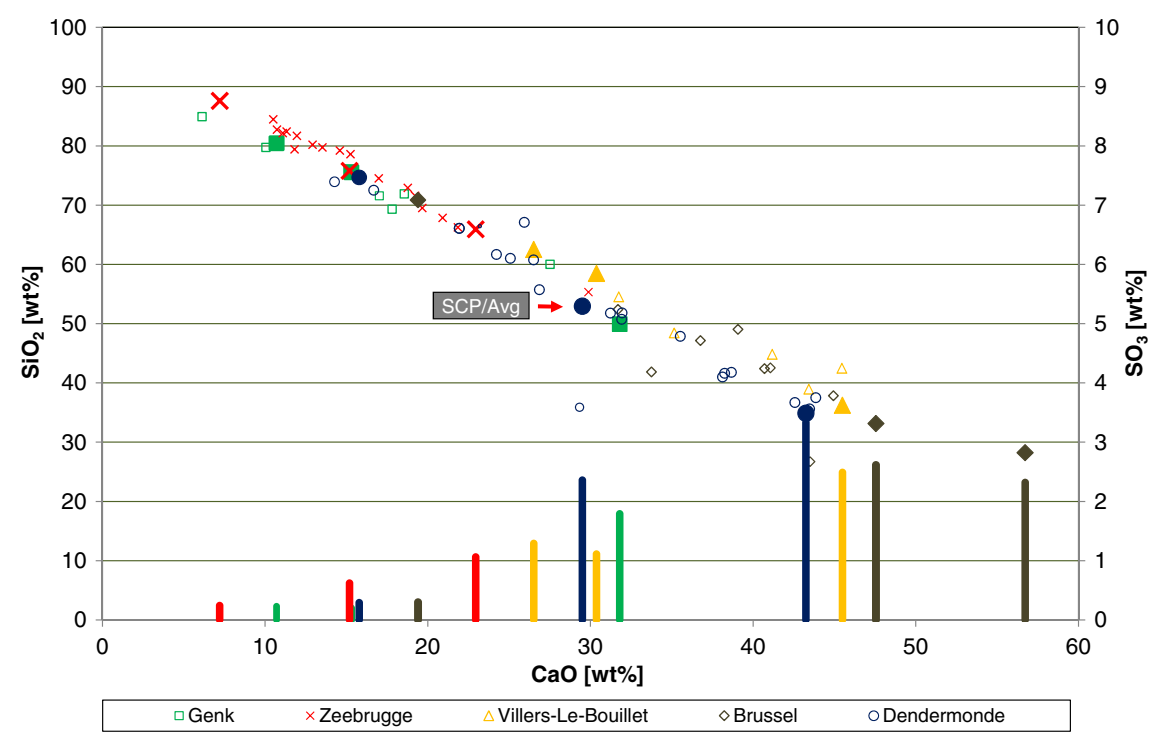

Fig. 2. $\mathrm{CaO}$ (\% by weight) as function of $\mathrm{SiO}_{2}(\%$ by weight $)$ for the 72 first and second batch sludge samples of the five selected concrete plants and $\mathrm{SO}_{3}$ (\% by weight) without LOI (bars) of the 15 selected sludge samples for PSD (bold) 
Table 2. Chemical and Mineralogical Limits of the Final Clinker

\begin{tabular}{|c|c|c|c|c|}
\hline Clinker & Unit & Antoing & Lixhe & Maastricht \\
\hline $\mathrm{Cl}$ & $\%$ by weight & $x<0.08$ & $x<0.08$ & $x<0.08$ \\
\hline $\mathrm{SO}_{3}$ & $\%$ by weight & $x<1.4$ & $x<1.2$ & $x<1.1$ \\
\hline $\mathrm{Na}_{2} \mathrm{Oeq}$ & $\%$ by weight & $x<1.2$ & $x<1.2$ & $x<1.2$ \\
\hline $\mathrm{MgO}$ & $\%$ by weight & $x<4.0$ & $x<4.0$ & $x<4.0$ \\
\hline $\mathrm{MgO} / \mathrm{Fe}_{2} \mathrm{O}_{3}$ & - & $x<1.40$ & $x<1.40$ & $x<1.40$ \\
\hline DOS level & - & $80<x<120$ & $80<x<120$ & $80<x<12$ \\
\hline \multicolumn{5}{|c|}{ If $\mathrm{MgO}<2 \%$ by weight } \\
\hline LSF_MgO & - & $98.2 \pm 0.5$ & $98.19 \pm 0.5$ & $98.20 \pm 0.5$ \\
\hline $\mathrm{C}_{3} \mathrm{~A}$ & $\%$ by weight & $7.35 \pm 0.5$ & $6.65 \pm 0.5$ & $7.33 \pm 0.5$ \\
\hline LiqSimple & $\%$ by weight & $19.18 \pm 0.5$ & $22.73 \pm 0.5$ & $22.97 \pm 0.5$ \\
\hline SR & - & $3.2 \pm 0.5$ & $2.6 \pm 0.5$ & $2.5 \pm 0.5$ \\
\hline
\end{tabular}

effects on the clinker kiln and insufficient clinker quality based on the cement standards EN 197-1, EN 197-2, and EN 196-3 [European Committee for Standardization (CEN) 2000a, b, c]. These limitations have to be taken into account while creating the simulations and corresponding lab clinkers for each clinker kiln/ factory. This makes it possible to evaluate the feasibility of applying a different ARM for each clinker kiln/factory.

Therefore, specific chemical limits for $\mathrm{SO}_{3}, \mathrm{Cl}$, alkalis, and $\mathrm{MgO}$ for each clinker factory were defined and listed in Table 2. With respect to the mineralogy of the final clinker, limits are also defined for the following three parameters: lime saturation factor (LSF), $\mathrm{C}_{3} \mathrm{~A}$, and the liquid phase [simple liquid (LiqSimple)], as defined by Taylor (1997). They are also incorporated in Table 2. The LSF governs the ratios of alite and belite, $\mathrm{C}_{3} \mathrm{~A}$ describes the expected celite content by means of the well-known Bogue calculation $\left(2.650 \cdot \mathrm{Al}_{2} \mathrm{O}_{3}-1.692 \cdot \mathrm{Fe}_{2} \mathrm{O}_{3}\right)$, and LiqSimple governs the ratio of $\mathrm{Al}_{2} \mathrm{O}_{3}$ to $\mathrm{Fe}_{2} \mathrm{O}_{3}$. By limiting these three parameters for the final clinker, the four metal oxides are sufficiently anchored for each factory. These limits were described in detail by Schoon et al. (2012).

\section{Controlling Parameters for Clinker Feed Calculation}

A simulation program based on linear equations was used to calculate CCM for each factory (CCM/Ant, Lxh, Maa) from their corresponding CRMs, in the case of the reference CCM. In the case of the alternative CCM, they were calculated partly from the described ARM. These compositions starting from CRM and ARM were merely adjusted to obtain the mineralogical settings, as already explained, without taking into account the ashes of the fuels that will actually be used to heat up the clinker meal in a real clinker kiln. The alternative CCMs were calculated to maximize the use of $\mathrm{SCP} / \mathrm{Avg}$ and Fines/Avg. Because of the high $\mathrm{SiO}_{2}$ (\% by weight) in both ARMs, it was expected that they would act as the $\mathrm{SiO}_{2}$ source in CCM, replacing loam or sabulous clay as classic raw materials (Table 1) in the case of CBR Lixhe and ENCI Maastricht.
Detailed calculations are provided by Schoon et al. (2012). Alkali sulfates decrease the viscosity of the melt, which results in increased alite formation (Taylor 1997). Without sufficient $\mathrm{SO}_{3}$ (\% by weight), the unbound alkali will increase the viscosity of the melt, which conversely results in decreased alite formation (Taylor 1997). To prevent this undesired decrease in alite, a stoichiometric balance is imposed between $\mathrm{SO}_{3}$ and alkali, expressed as the degree of sulfatization (DOS) value by Hewlett (1988). This value is calculated by Eq. (1), using the chemical analysis of the final clinker

$$
\text { DOS }=77.41 \times \mathrm{SO}_{3} /\left(\mathrm{Na}_{2} \mathrm{O}+\mathrm{K}_{2} \mathrm{O} \times 0.658\right)
$$

Currently, DOS levels between 80 and $120 \%$ by weight are used in the three clinker factories. Furthermore, it was stated by Taylor (1997) that the burnability of the CCM or the ease by which free lime can be reduced in the kiln to an acceptable value, decreases with increased LSF_MgO [Eq. (2)] or saturation rate (SR) [Eq. (3)]

$$
\begin{gathered}
\mathrm{LSF}-\mathrm{MgO}=100 \times(\mathrm{CaO}+0.75 \times \mathrm{MgO}) / \\
\left(2.8 \times \mathrm{SiO}_{2}+1.18 \times \mathrm{Al}_{2} \mathrm{O}_{3}+0.65 \times \mathrm{Fe}_{2} \mathrm{O}_{3}\right) \\
\mathrm{SR}=\mathrm{SiO}_{2} /\left(\mathrm{Al}_{2} \mathrm{O}_{3}+\mathrm{Fe}_{2} \mathrm{O}_{3}\right)
\end{gathered}
$$

By keeping both values constant, the burnability will not be influenced by chemical variations.

\section{Results and Discussion}

\section{Evaluation of the Concrete Sludge Samples before Treatment}

As shown in Fig. 1, the first batch of concrete sludge samples collected in the beginning of 2011 already showed large chemical variation. The second batch of concrete sludge samples of the five selected concrete plants, collected over a time period (2011-2012) of two years (Fig. 2), which gave a total of 87 samples, had a comparable chemical variation to the first batch. This demonstrates that the 20 samples collected in the beginning of 2011 already provided a representative image of the chemical variation of concrete sludge samples in Belgium.

Second, the chemical variation, although still pronounced, improves visually in Fig. 2 if the sludge is collected for each concrete plant individually. Nevertheless, based on the calculated average, $\mathrm{SD}$, and standard error of the mean (SEM) for both $\mathrm{CaO}$ (\% by weight) and $\mathrm{SiO}_{2}$ (\% by weight), the improvement of the chemical variation if collected by individually concrete plant is demonstrated to be rather marginal. (Table 3). There was no influence of the seasons observed in the sludge samples of the two concrete plants where samples were collected each month: IB Dendermonde

\begin{tabular}{|c|c|c|c|c|c|c|c|}
\hline Concrete sludge & Unit & Total & IB Brussel & IB Dendermonde & IB Genk & IB Villers-Le-Bouillet & IB Zeebrugge \\
\hline Amount & - & 72 & 11 & 23 & 9 & 8 & 21 \\
\hline Average $\mathrm{CaO}$ & $\%$ by weight & 26.74 & 39.55 & 30.29 & 17.21 & 37.41 & 16.16 \\
\hline $\mathrm{SD} \mathrm{CaO}$ & $\%$ by weight & 12.13 & 9.57 & 9.06 & 8.22 & 7.42 & 5.55 \\
\hline SEM CaO & $\%$ by weight & 1.26 & 2.89 & 1.89 & 2.74 & 2.63 & 1.21 \\
\hline Average $\mathrm{SiO}_{2}$ & $\%$ by weight & 59.81 & 42.93 & 53.03 & 71.49 & 48.31 & 75.44661 \\
\hline $\mathrm{SD} \mathrm{SiO}_{2}$ & $\%$ by weight & 16.74 & 12.36 & 13.32 & 10.89 & 9.44 & 7.98 \\
\hline $\mathrm{SEM} \mathrm{SiO}_{2}$ & $\%$ by weight & 1.74 & 3.73 & 2.78 & 3.63 & 3.34 & 1.74 \\
\hline
\end{tabular}
(Fig. 3) and IB Zeebrugge (Fig. 4). Furthermore, a strong relationship was noticed between the chemical composition of the sludge

Table 3. Statistical Interpretation of the Chemical Variations of the Concrete Sludge Samples 


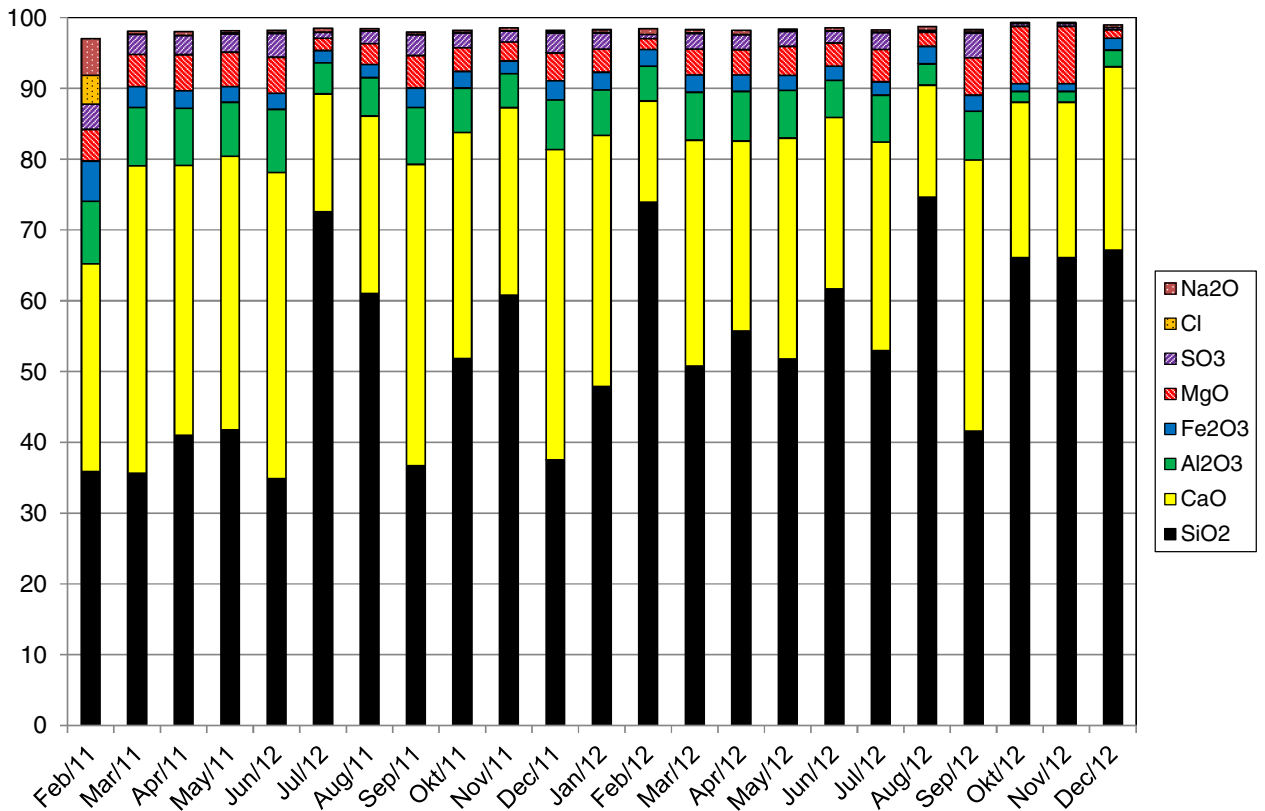

Fig. 3. Chemical composition without LOI of the sludge samples from IB Dendermonde

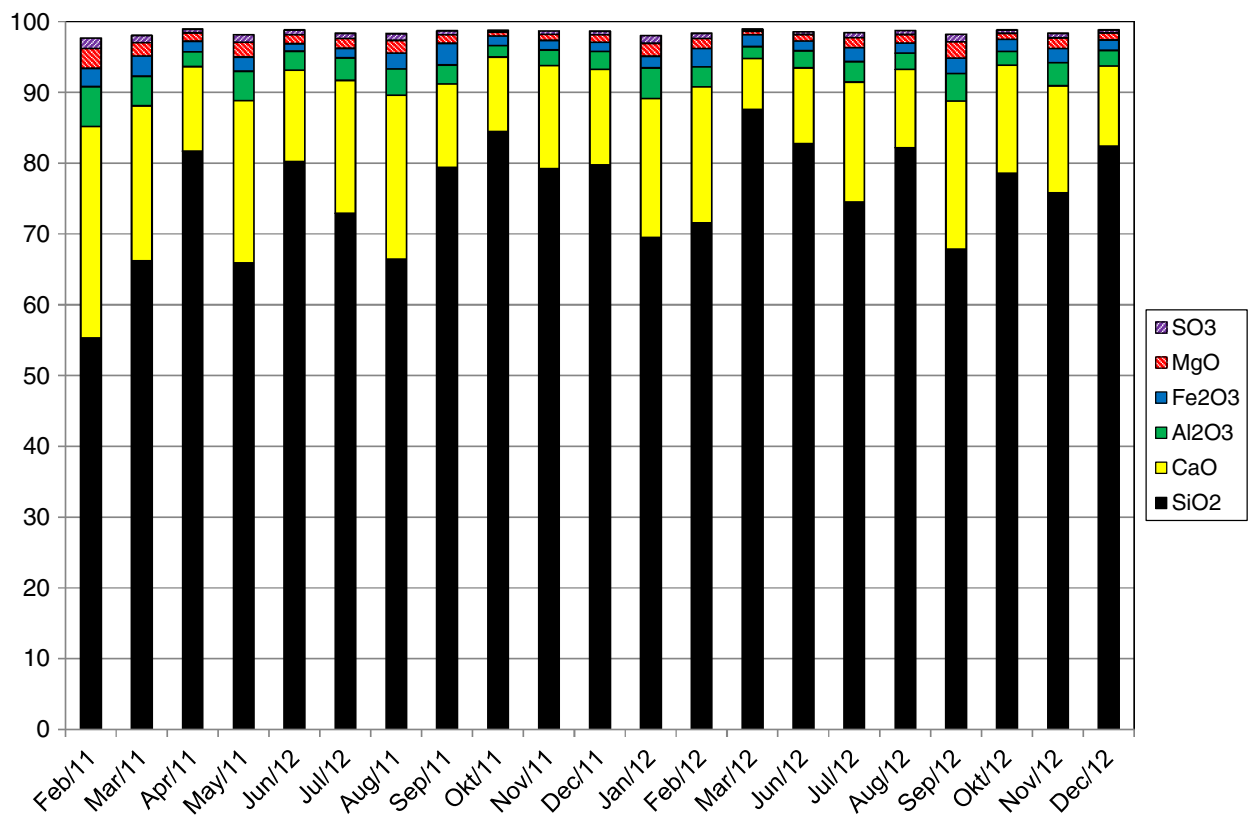

Fig. 4. Chemical composition without LOI of the sludge samples from IB Zeebrugge

and its $\mathrm{SO}_{3}$ (\% by weight). The higher $\mathrm{CaO}$ (\% by weight) and lower $\mathrm{SiO}_{2}$ (\% by weight) without loss on ignition (LOI) present in the sludge, the higher the $\mathrm{SO}_{3}$ (\% by weight) becomes, as demonstrated in Fig. 2, in which the $\mathrm{SO}_{3}$ (\% by weight) of the 15 selected concrete samples is additionally plotted. This relationship is also demonstrated in Fig. 5, in which $\mathrm{CaO}$ (\% by weight) of all 87 samples is plotted as a function of their $\mathrm{SO}_{3}$ (\% by weight). Although $\mathrm{SO}_{3}$ (\% by weight) can also be present in the aggregate fraction, especially when sea gravel and sea sand is involved, the largest part of the $\mathrm{SO}_{3}$ in the sludge is delivered by the cement fraction. As shown in Fig. 5, the $\mathrm{SO}_{3}$ (\% by weight) in concrete sludge can increase to $3.5 \%$ by weight, which indicates a high cement content and perhaps an accumulation of the water soluble $\mathrm{SO}_{3}$ coming from the cement hydrates.
PSD analysis of the 15 selected sludge samples showed also some interesting findings. The upper sieve size $(D)$ of the 15 selected sludge samples is as defined in NBN EN 1097-6 (2000) between 4 and $16 \mathrm{~mm}$, and the samples have sand fractions varying from 61 to $100 \%$ by weight. Additionally, the fines fraction $(<250 \mu \mathrm{m})$ shows large variation in this pool of 15 samples, from 8 to $58 \%$ by weight. When focusing on the fraction smaller than $63 \mu \mathrm{m}$, a variation between 0 and $20 \%$ by weight is found in the 15 sludge samples.

TGA analyses clearly show that the five concrete sludge samples have mass losses by dehydration of hydration products between 125 and $650^{\circ} \mathrm{C}$ and decarbonation peaks between 650 and $900^{\circ} \mathrm{C}$ when heated (Table 4). The hydration products result from the reacted cement, whereas the carbonated products probably arise 


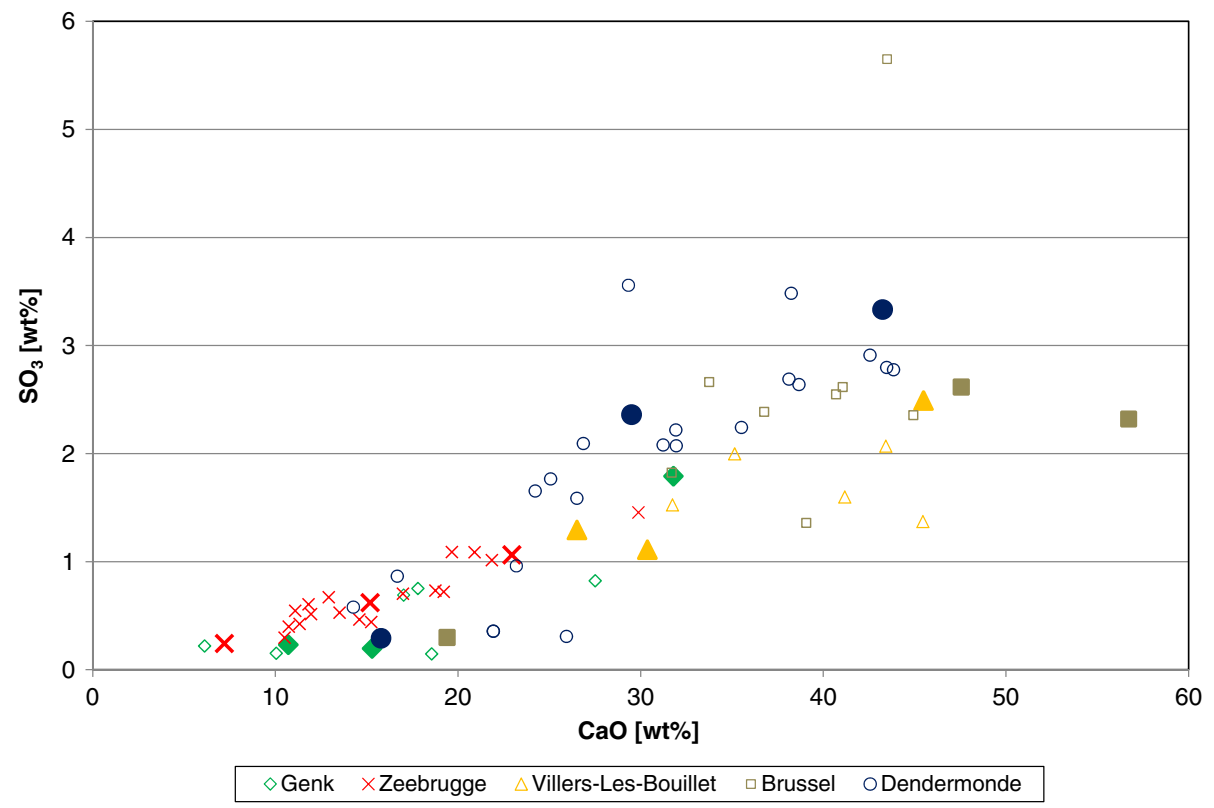

Fig. 5. The relationship between $\mathrm{CaO}$ (\% by weight) and $\mathrm{SO}_{3}$ (\% by weight) for the 87 concrete sludge samples

from limestone, originating from the cement or the aggregates present in the sludge. The results of this TGA/DTA evaluation are presented in Table 4.

\section{Evaluation of the Concrete Sludge Samples after a Separation Phase}

The large chemical variation and high $\mathrm{SiO}_{2}$ (\% by weight) indicate that concrete sludge does not have high potential as ARM for portland clinker production if the concrete sludge cannot be altered. Although it was foreseen that a crushing action combined with a separation phase at $250 \mu \mathrm{m}$ would separate the hydrated cement from the aggregate fraction, as demonstrated by Schoon et al. (unpublished data, 2014), the chemical composition and chemical variation did not significantly improve for the recovered fines fraction $(<250 \mu \mathrm{m})$ (Tables 5 and 6) compared to the total concrete sludge sample (Fig. 2) from which the fines fraction originated. The fines fraction $(<250 \mu \mathrm{m})$ had similar chemical compositions and variation, and there was a clear relationship between the chemistry $\left(\mathrm{CaO}\right.$ and $\left.\mathrm{SiO}_{2}\right)$ and $\mathrm{SO}_{3}(\%$ by weight) (Fig. 6), as was also demonstrated for the concrete sludge samples.

TGA analyses of the three separation fractions for the sludge samples similar to the average chemical composition of their concrete plant (Table 4) provide a clear view on the composition of the three separated fractions and the sludge sample itself. As expected, the fraction $<250 \mu \mathrm{m}$ contains cement hydration products visible between 125 and $650^{\circ} \mathrm{C}$, as was also observed for recycled concrete

Table 4. Properties of Three Size Fractions of the Five Selected Sludge Samples

\begin{tabular}{|c|c|c|c|c|c|c|c|c|c|}
\hline $\begin{array}{l}\text { Fractions } \\
(\mu \mathrm{m})\end{array}$ & $\begin{array}{c}\text { Distribution } \\
\text { (\% by } \\
\text { weight) }\end{array}$ & $\begin{array}{c}\mathrm{SiO}_{2} \\
\text { (\% by } \\
\text { weight) }\end{array}$ & $\begin{array}{c}\mathrm{CaO} \\
\text { (\% by } \\
\text { weight) }\end{array}$ & $\begin{array}{c}\mathrm{SiO}_{3} \\
(\% \text { by } \\
\text { weight })\end{array}$ & $\begin{array}{c}\text { LOI } 975^{\circ} \mathrm{C}\left(\mathrm{O}_{2}\right) \\
(\% \text { by } \\
\text { weight })\end{array}$ & $\begin{array}{c}125-900^{\circ} \mathrm{C} \\
\text { (\% by } \\
\text { weight })\end{array}$ & $\begin{array}{c}125-650^{\circ} \mathrm{C} \\
(\% \text { by } \\
\text { weight })\end{array}$ & $\begin{array}{c}650-900^{\circ} \mathrm{C} \\
\text { (\% by } \\
\text { weight })\end{array}$ & $\begin{array}{c}\text { Decarb/CaO } \\
\text { (\% by } \\
\text { weight })\end{array}$ \\
\hline Brussel & 100 & 22.14 & 44.49 & 1.82 & 21.56 & -22.12 & -9.15 & -12.97 & -0.29 \\
\hline$>500$ & 66 & 15.89 & 46.17 & 1.27 & 28.93 & -24.41 & -7.46 & -16.95 & -0.37 \\
\hline $250<x<500$ & 9 & 37.80 & 37.45 & 1.24 & 16.55 & -16.30 & -10.91 & -5.39 & -0.14 \\
\hline$<250$ & 25 & 22.41 & 41.34 & 2.40 & 21.91 & -18.15 & -12.96 & -5.19 & -0.13 \\
\hline Dendermonde & 100 & 45.53 & 25.37 & 2.03 & 14.00 & -14.34 & -10.83 & -3.52 & -0.14 \\
\hline$>500$ & 43 & 46.74 & 24.53 & 2.30 & 14.22 & -11.91 & -8.89 & -3.02 & -0.12 \\
\hline $250<x<500$ & 6 & 73.09 & 11.64 & 1.01 & 7.34 & -6.25 & -4.55 & -1.70 & -0.15 \\
\hline$<250$ & 51 & 40.51 & 26.55 & 2.21 & 17.43 & -17.35 & -13.20 & -4.15 & -0.16 \\
\hline Genk & 100 & 67.04 & 13.57 & 0.17 & 11.27 & -11.21 & -2.69 & -8.52 & -0.63 \\
\hline$>500$ & 80 & 65.73 & 14.55 & 0.13 & 11.82 & -11.71 & -1.82 & -9.89 & -0.68 \\
\hline $250<x<500$ & 12 & 80.34 & 6.27 & 0.21 & 4.99 & -3.54 & -1.35 & -2.19 & -0.35 \\
\hline$<250$ & 8 & 53.08 & 17.90 & 1.17 & 13.51 & -17.71 & -13.37 & -4.34 & -0.24 \\
\hline Villers-Le-Bouillet & 100 & 48.04 & 24.94 & 0.91 & 17.87 & -17.79 & -8.72 & -9.07 & -0.36 \\
\hline$>500$ & 40 & 37.39 & 30.52 & 0.92 & 22.94 & -18.37 & -5.72 & -12.65 & -0.41 \\
\hline $250<x<500$ & 16 & 82.77 & 6.59 & 0.21 & 4.88 & -4.83 & -1.43 & -3.39 & -0.51 \\
\hline$<250$ & 44 & 30.90 & 31.53 & 1.77 & 23.02 & -21.98 & -14.10 & -7.89 & -0.25 \\
\hline Zeebrugge & 100 & 83.12 & 6.84 & 0.23 & 5.11 & -5.67 & -2.85 & -6.68 & -0.98 \\
\hline$>500$ & 49 & 71.27 & 13.27 & 0.37 & 9.86 & -6.64 & -3.94 & -10.57 & -0.80 \\
\hline $250<x<500$ & 31 & 88.20 & 4.53 & 0.10 & 3.37 & -2.28 & -0.10 & -2.18 & -0.48 \\
\hline$<250$ & 20 & 74.25 & 10.62 & 0.53 & 6.49 & -8.57 & -4.46 & -4.11 & -0.39 \\
\hline
\end{tabular}

Note: $125-650^{\circ} \mathrm{C}=$ hydration products; $650-900^{\circ} \mathrm{C}=$ decarbonation; Decarb $/ \mathrm{CaO}=650-900^{\circ} \mathrm{C} / \mathrm{CaO}$; boldface indicates the complete sludge samples. 
Table 5. Average Chemical Compositions of the Three Selected Sludge Samples from Each Concrete Plant

\begin{tabular}{|c|c|c|c|c|c|c|}
\hline & & Brussel & Dendermonde & Genk & Villers-Le-Bouillet & Zeebrugge \\
\hline ARM & Unit & Average & Average & Average & Average & Average \\
\hline $\mathrm{CaO}$ & $\%$ by weight & 33.08 & 24.53 & 17.01 & 27.76 & 13.54 \\
\hline $\mathrm{SiO}_{2}$ & $\%$ by weight & 36.78 & 46.60 & 61.67 & 43.14 & 69.75 \\
\hline $\mathrm{Al}_{2} \mathrm{O}_{3}$ & $\%$ by weight & 4.54 & 5.14 & 3.98 & 4.26 & 2.71 \\
\hline $\mathrm{Fe}_{2} \mathrm{O}_{3}$ & $\%$ by weight & 1.80 & 1.89 & 2.62 & 1.55 & 1.72 \\
\hline $\mathrm{K}_{2} \mathrm{O}$ & $\%$ by weight & 0.53 & 0.52 & 0.53 & 0.50 & 0.47 \\
\hline $\mathrm{Na}_{2} \mathrm{O}$ & $\%$ by weight & 0.37 & 0.34 & 0.22 & 0.14 & 0.37 \\
\hline $\mathrm{SO}_{3}$ & $\%$ by weight & 1.39 & 1.64 & 0.65 & 1.32 & 0.57 \\
\hline $\mathrm{MgO}$ & $\%$ by weight & 2.44 & 3.23 & 2.06 & 2.40 & 1.23 \\
\hline $\mathrm{TiO}_{2}$ & $\%$ by weight & 0.32 & 0.32 & 0.27 & 0.32 & 0.15 \\
\hline $\mathrm{P}_{2} \mathrm{O}_{5}$ & $\%$ by weight & 0.15 & 0.15 & 0.14 & 0.12 & 0.13 \\
\hline $\mathrm{Cl}$ & $\%$ by weight & 0.04 & 0.06 & 0.02 & 0.05 & 0.07 \\
\hline LOI $975^{\circ} \mathrm{C}\left(\mathrm{O}_{2}\right)$ & $\%$ by weight & 18.25 & 15.24 & 10.59 & 18.15 & 9.10 \\
\hline
\end{tabular}

Table 6. Average Chemical Compositions of the Three Selected Sludge Fines from Each Concrete Plant

\begin{tabular}{|c|c|c|c|c|c|c|}
\hline & & Brussel & Dendermonde & Genk & Villers-Le-Bouillet & Zeebrugge \\
\hline $\mathrm{ARM}$ & Unit & Average & Average & Average & Average & Average \\
\hline $\mathrm{CaO}$ & $\%$ by weight & 30.02 & 21.85 & 18.74 & 31.56 & 18.86 \\
\hline $\mathrm{SiO}_{2}$ & $\%$ by weight & 38.23 & 50.78 & 55.85 & 31.08 & 58.10 \\
\hline $\mathrm{Al}_{2} \mathrm{O}_{3}$ & $\%$ by weight & 4.91 & 5.12 & 5.13 & 5.48 & 4.70 \\
\hline $\mathrm{Fe}_{2} \mathrm{O}_{3}$ & $\%$ by weight & 2.03 & 1.61 & 2.71 & 1.79 & 1.84 \\
\hline $\mathrm{K}_{2} \mathrm{O}$ & $\%$ by weight & 0.54 & 0.66 & 0.69 & 0.47 & 0.73 \\
\hline $\mathrm{Na}_{2} \mathrm{O}$ & $\%$ by weight & 0.28 & 0.31 & 0.27 & 0.16 & 0.52 \\
\hline $\mathrm{SO}_{3}$ & $\%$ by weight & 1.80 & 1.68 & 1.03 & 1.81 & 1.03 \\
\hline $\mathrm{MgO}$ & $\%$ by weight & 2.67 & 3.10 & 2.79 & 3.46 & 2.20 \\
\hline $\mathrm{TiO}_{2}$ & $\%$ by weight & 0.36 & 0.32 & 0.37 & 0.45 & 0.26 \\
\hline $\mathrm{P}_{2} \mathrm{O}_{5}$ & $\%$ by weight & 0.20 & 0.16 & 0.17 & 0.15 & 0.17 \\
\hline $\mathrm{Cl}$ & $\%$ by weight & 0.04 & 0.07 & 0.02 & 0.07 & 0.13 \\
\hline LOI $975^{\circ} \mathrm{C}\left(\mathrm{O}_{2}\right)$ & $\%$ by weight & 18.60 & 14.08 & 11.96 & 23.19 & 11.24 \\
\hline
\end{tabular}

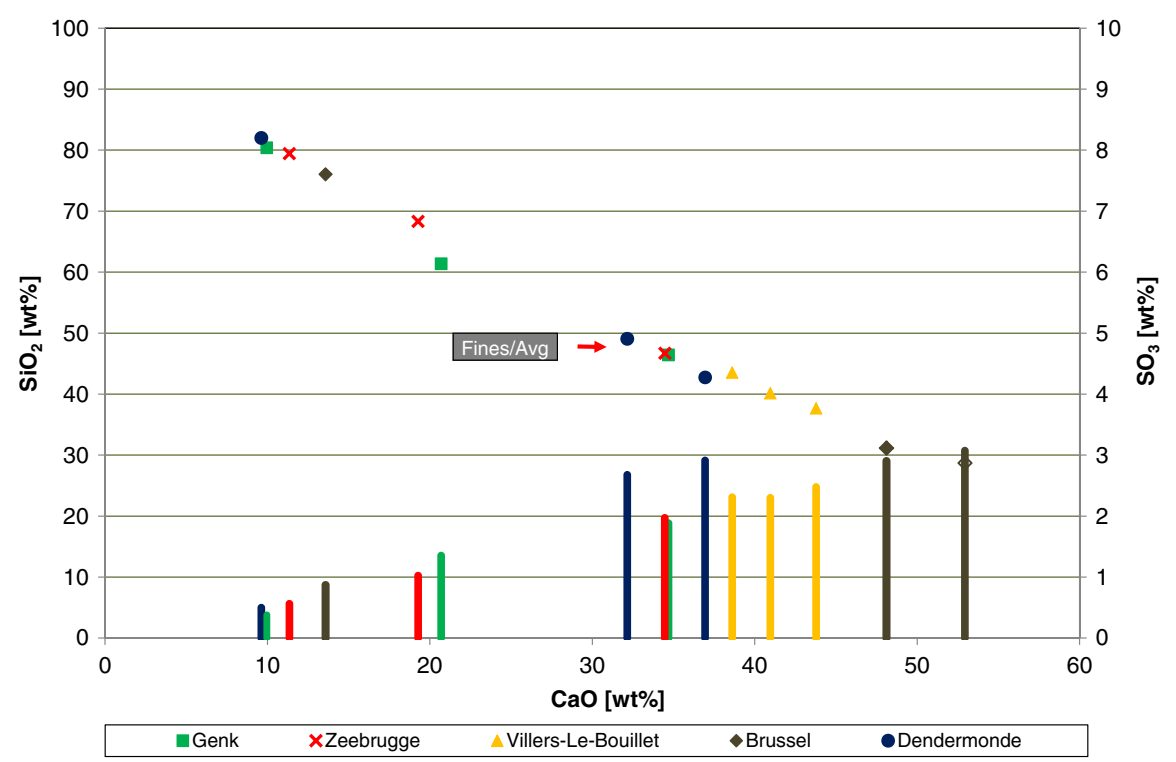

Fig. 6. Fines $(<250 \mu \mathrm{m})$ of the 15 sludge samples from the five selected concrete plants

(Schoon et al., unpublished data, 2014). Interestingly, the $>500 \mu \mathrm{m}$ fraction in each of the 15 analyzed sludge samples contained comparable cement hydration products and have comparable $\mathrm{CaO}(\%$ by weight $)$ and $\mathrm{SiO}_{2}(\%$ by weight). The fraction between 250 and $500 \mu \mathrm{m}$ consisted of a low amount of cement hydrates.
TGA analysis between 650 and $900^{\circ} \mathrm{C}$ demonstrates less decarbonation of $\mathrm{CaCO}_{3}$ (\% by weight) in the $<250 \mu \mathrm{m}$ fraction than in the corresponding sludge sample itself. By presenting the decarbonation between 650 and $900^{\circ} \mathrm{C}$ as a function of $\mathrm{CaO}$ (\% by weight) (Decarb/CaO), it is clear that the $<250 \mu \mathrm{m}$ fraction consists of less 
Table 7. Chemical Compositions of the Three Separation Fractions of SCP/Avg

\begin{tabular}{|c|c|c|c|c|c|}
\hline & & Fraction & Fraction & Fines/Avg & SBC/Avg \\
\hline Fractions $(\mu \mathrm{m})$ & Unit & $>500$ & $250<x<500$ & $<250$ & Total \\
\hline$\%$ by weight & - & 43 & 6 & 51 & 100 \\
\hline $\mathrm{CaO}$ & $\%$ by weight & 24.53 & 11.64 & 26.55 & 25.37 \\
\hline $\mathrm{SiO}_{2}$ & $\%$ by weight & 46.74 & 73.09 & 40.51 & 45.53 \\
\hline $\mathrm{Al}_{2} \mathrm{O}_{3}$ & $\%$ by weight & 5.55 & 3.04 & 5.81 & 5.66 \\
\hline $\mathrm{Fe}_{2} \mathrm{O}_{3}$ & $\%$ by weight & 1.51 & 0.87 & 1.60 & 1.65 \\
\hline $\mathrm{K}_{2} \mathrm{O}$ & $\%$ by weight & 0.53 & 0.49 & 0.59 & 0.54 \\
\hline $\mathrm{Na}_{2} \mathrm{O}$ & $\%$ by weight & 0.30 & 0.21 & 0.24 & 0.26 \\
\hline $\mathrm{SO}_{3}$ & $\%$ by weight & 1.97 & 1.01 & 2.21 & 2.03 \\
\hline $\mathrm{MgO}$ & $\%$ by weight & 3.76 & 1.87 & 4.08 & 3.93 \\
\hline $\mathrm{TiO}_{2}$ & $\%$ by weight & 0.37 & 0.19 & 0.42 & 0.41 \\
\hline $\mathrm{P}_{2} \mathrm{O}_{5}$ & $\%$ by weight & 0.18 & 0.09 & 0.18 & 0.17 \\
\hline $\mathrm{Cl}$ & $\%$ by weight & 0.05 & 0.03 & 0.07 & 0.06 \\
\hline LOI $975^{\circ} \mathrm{C}\left(\mathrm{O}_{2}\right)$ & $\%$ by weight & 14.22 & 7.34 & 17.43 & 14.00 \\
\hline
\end{tabular}

Table 8. Compositions of the Different Clinker Meals Created to be Fed to the Static Kiln

\begin{tabular}{|c|c|c|c|c|c|c|c|c|}
\hline CCM/Ant & $\begin{array}{c}\text { CRM (Ant) }+ \\
\text { ARM }\end{array}$ & $\begin{array}{c}\text { Quantity } \\
\text { (\% by weight) }\end{array}$ & $\mathrm{CCM} / \mathrm{Lxh}$ & $\begin{array}{c}\text { CRM (Lxh) }+ \\
\text { ARM }\end{array}$ & $\begin{array}{c}\text { Quantity } \\
\text { (\% by weight) }\end{array}$ & $\mathrm{CCM} / \mathrm{Maa}$ & $\begin{array}{c}\text { CRM (Maa) }+ \\
\text { ARM }\end{array}$ & $\begin{array}{c}\text { Quantity } \\
\text { (\% by weight }\end{array}$ \\
\hline \multirow[t]{7}{*}{$\mathrm{CCM} / \mathrm{Ant} / \mathrm{Ref}$} & Poor limestone & 55.25 & \multirow[t]{7}{*}{$\mathrm{CCM} / \mathrm{Lxh} / \mathrm{Ref}$} & Tufa & 79.44 & \multirow[t]{7}{*}{ CCM/Maa/Ref } & Marl & 84.38 \\
\hline & Rich limestone & 37.50 & & Loam & 6.63 & & Sabulous clay & 2.90 \\
\hline & Fly ash & 6.38 & & Fly ash & 12.34 & & Fly ash & 11.02 \\
\hline & Iron carrier & 0.87 & & Iron carrier & 1.59 & & Iron carrier & 1.70 \\
\hline & SCP/Avg & 0.00 & & SCP/Avg & 0.00 & & SCP/Avg & 0.00 \\
\hline & Fines/Avg & 0.00 & & Fines/Avg & 0.00 & & Fines/Avg & 0.00 \\
\hline & Sum & 100.00 & & Sum & 100.00 & & Sum & 100.00 \\
\hline \multirow[t]{7}{*}{$\mathrm{CCM} / \mathrm{Ant} / \mathrm{SCP}$} & Poor limestone & 32.76 & \multirow[t]{7}{*}{$\mathrm{CCM} / \mathrm{Lxh} / \mathrm{SCP}$} & Tufa & 75.20 & \multirow[t]{7}{*}{$\mathrm{CCM} / \mathrm{Maa} / \mathrm{SCP}$} & Marl & 77.14 \\
\hline & Rich limestone & 54.71 & & Loam & 2.01 & & Sabulous clay & 1.62 \\
\hline & Fly ash & 6.74 & & Fly ash & 11.36 & & Fly ash & 8.61 \\
\hline & Iron carrier & 0.91 & & Iron carrier & 1.80 & & Iron carrier & 1.68 \\
\hline & SCP/Avg & 4.87 & & SCP/Avg & 9.64 & & SCP/Avg & 10.94 \\
\hline & Fines/Avg & 0.00 & & Fines/Avg & 0.00 & & Fines/Avg & 0.00 \\
\hline & Sum & 100.00 & & Sum & 100.00 & & Sum & 100.00 \\
\hline \multirow[t]{7}{*}{$\mathrm{CCM} /$ Ant/Fines } & Poor limestone & 5.91 & \multirow[t]{7}{*}{ CCM/Lxh/Fines } & Tufa & 75.31 & \multirow[t]{7}{*}{ CCM/Maa/Fines } & Marl & 76.32 \\
\hline & Rich limestone & 70.46 & & Loam & 0.00 & & Sabulous clay & 0.00 \\
\hline & Fly ash & 6.36 & & Fly ash & 12.78 & & Fly ash & 10.31 \\
\hline & Iron carrier & 0.97 & & Iron carrier & 1.54 & & Iron carrier & 1.56 \\
\hline & SCP/Avg & 0.00 & & SCP/Avg & 0.00 & & SCP/Avg & 0.00 \\
\hline & Fines/Avg & 16.30 & & Fines/Avg & 10.37 & & Fines/Avg & 11.80 \\
\hline & Sum & 100.00 & & Sum & 100.00 & & Sum & 100.00 \\
\hline
\end{tabular}

$\mathrm{CaCO}_{3}$ than the sludge sample itself. The $<250 \mu$ m fraction will decrease decarbonation in the CCM more than its corresponding sludge sample when equally dosed to an alternative CCM. It is the present cement stone derivatives, and not the total $\mathrm{CaO}(\%$ by weight), although related, that will determine the potential of concrete sludge to reduce the decarbonation in the CCM. This will be further demonstrated in the next sections. The fraction between 250 and $500 \mu \mathrm{m}$ consists of an excess of $\mathrm{SiO}_{2}$ (\% by weight) demonstrating the presence of quartz particles and much lower $\mathrm{CaO}$ (\% by weight) and $\mathrm{SO}_{3}$ (\% by weight), which indicates, together with the lower mass losses between 125 and $650^{\circ} \mathrm{C}$, that smaller cement fractions are present than in the $>500$ and $<250 \mu \mathrm{m}$ fractions. These quartz particles have their origin from the fraction of aggregates of the concrete sludge. The slightly higher $\mathrm{SiO}_{2}(\%$ by weight) in the $>500 \mu \mathrm{m}$ fraction originates from the quartz particles that were also present in the fraction between 250 and $500 \mu \mathrm{m}$. To demonstrate this trend in more detail, a full chemical analysis and a TGA analysis of the three fractions of the sludge sample SCP/Avg is presented in Table 7 and Fig. 7.
The findings in this section indicates that a crushing action on $4 \mathrm{~mm}$ and separation on $250 \mu \mathrm{m}$ particles is not sufficient to recover all hydrated cement in the $<250 \mu \mathrm{m}$ fraction, as was expected, and which was demonstrated successfully to recycle fines into ARM generated from recycled concrete aggregates, as demonstrated by Schoon et al. (unpublished data, 2014). One explanation could be that the composition of concrete sludge is not comparable with that of recycled concrete (Schoon et al., unpublished data, 2014). It is composed of the fine particles of the different raw materials (cement, sand, raw aggregates, and fly ash) used to produce concrete. This explains why hydrated cement is much more present in the sludge than in the recycled concrete (Schoon et al., unpublished data, 2014). The increased presence of the hydrated cement and the lack of an aggregate structure negatively influence the crushing action. The cement present in the concrete sludge will have reacted with an excess of water in the concrete sludge basin before it is collected, making the cement stone in the sludge sample very weak after hardening. In this way, the cement stone crumbles instead of breaking apart, leaving many cement stone particles in the fraction 


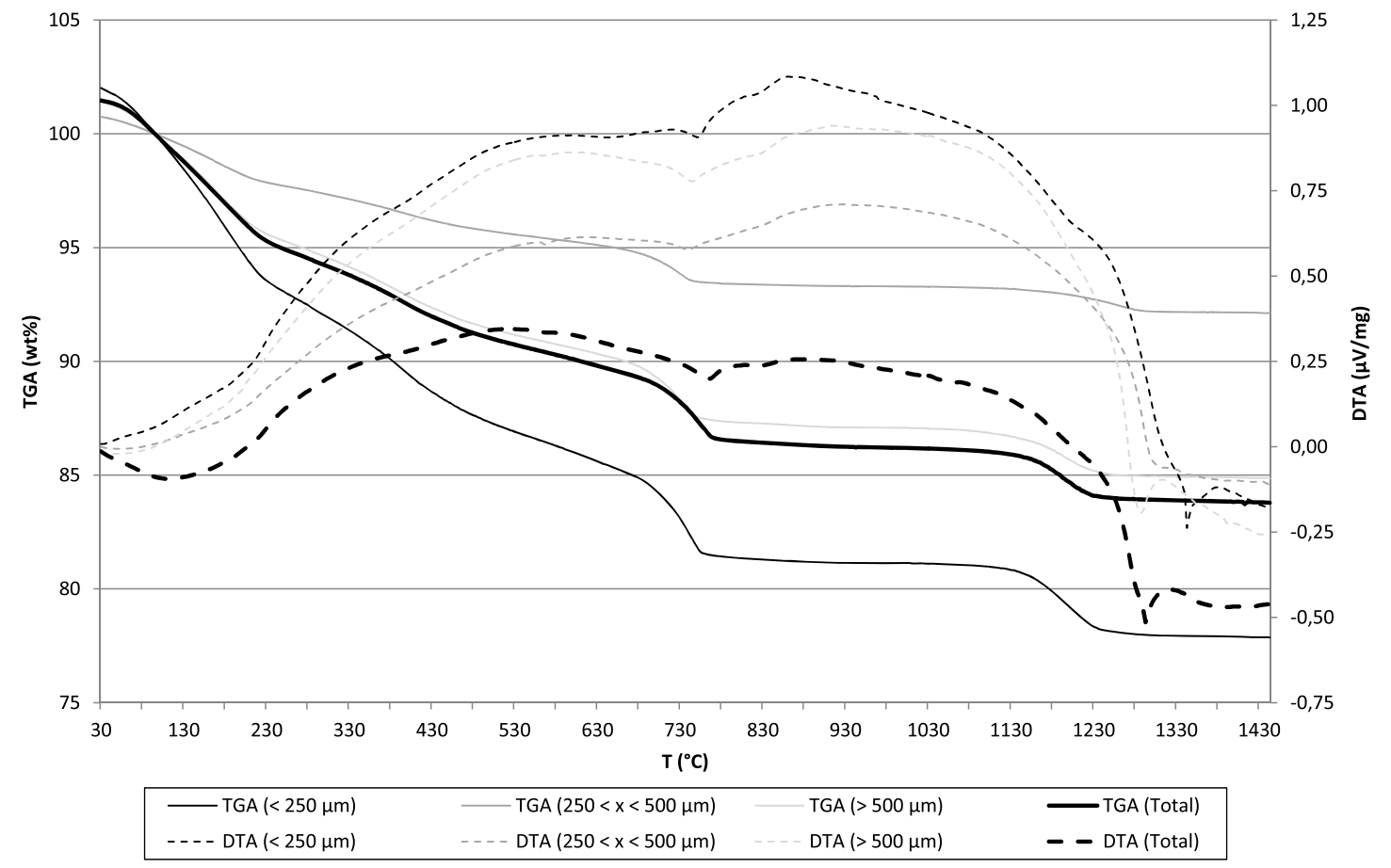

Fig. 7. TGA/DTA analysis of SCP/Avg and its three fractions after a separation phase

larger than $500 \mu \mathrm{m}$. Therefore, more intensive crushing action is necessary to separate the hydrated cement stone fraction from the aggregates fraction, although questions may be raised about the economic feasibility and necessity of this intensified crushing action. One reason to strongly consider this intensified crushing action could be the grindability of the coarse quartz particles (Schoon et al., unpublished data, 2014; Kakali and Tsivilis 1993; Tsamatsoulis 1979; Christensen 1979; Ghosh 1991) present in fractions $250<x<500 \mu \mathrm{m}$ and $>500 \mu \mathrm{m}$ and their influence on the burnability of the clinker. This was further investigated and discussed in the next sections.

\section{Clinker Feed Calculations and Preparations}

Although the chemical compositions of SCP/Avg and Fines/ Avg are comparable, the possible influence on the burnability by the presence of the coarse quartz particles in SCP/Avg could be investigated when sintering alternative CCM with both materials. Therefore, they were both used as ARMs for the calculation and preparation of clinker feed.

As demonstrated in Table 8, Fines/Avg completely replaced the classic $\mathrm{SiO}_{2}$ source in CCM/Lxh/Fines and CCM/Maa/Fines. The maximization of SCP/Avg was limited by the required $\mathrm{CaO}$ (\% by weight) defined by LSF and LiqSimple of both kilns; therefore, it only partly replaced the complete $\mathrm{SiO}_{2}$ source. Because the $\mathrm{SiO}_{2}$ (\% by weight) of the ARM is lower than those present in the classic $\mathrm{SiO}_{2}$ sources (Table 1), higher volumes of the ARMs have to be dosed to attain the required $\mathrm{SiO}_{2}$ (\% by weight). To compensate for these higher volumes, limestone dosages are decreased. Because less limestone (Table 1 ) is dosed, $\mathrm{CaO}$ (\% by weight) in the $\mathrm{CCM}$ must be compensated by the $\mathrm{CaO}$ (\% by weight) present in the ARMs. In the case of CBR Antoing, the influence on $\mathrm{CaO}$ (\% by weight) acted as a limitation in both alternative CCMs (ARM/Ant/SCP and ARM/Ant/Fines). Maximization of the two different ARM materials is different than for the two previous factories because CBR Antoing does not use a real $\mathrm{SiO}_{2}$ source. The necessary $\mathrm{SiO}_{2}$ is delivered by their two limestone sources, particularly poor limestone (Table 1). Fines/Avg, owing to their higher $\mathrm{CaO}$ (\% by weight) and lower $\mathrm{SiO}_{2}$ (\% by weight), can be dosed in higher quantities than SCP/Avg.

\section{Evaluation of the Artificially Produced Portland Clinkers}

The alternative CCMs show small but quantifiable decreases in decarbonation mass loss (Anorg $\mathrm{CO}_{2}$ ) compared to their reference (Table 9), which are more pronounced when using Fines/Avg than the corresponding SCP/Avg. The reason for this difference was already explained in the previous sections. An estimation was made of the measurement of decarbonation mass loss to demonstrate the $\mathrm{CaCO}_{3}$ (\% by weight) present in the reference and alternative $\mathrm{CCM}$, and to quantify the required decarbonation energy (Decarb $\mathrm{E} \mathrm{CaCO}_{3}$ Der) from the known reaction enthalpy of $1,782 \mathrm{~kJ} / \mathrm{kg}$ for $\mathrm{CaCO}_{3}$ stated by Taylor (1997). This decarbonation energy can also be measured by DTA analysis, as presented in Table 9. Both methods demonstrate a decrease in decarbonation energy in the alternative CCMs compared to their reference.

The XRD analysis with Rietveld refinement of the final clinkers, presented in Tables 10 and 11, shows mineralogical weight percentages that are on the same order of magnitude, but nevertheless

Table 9. TGA/DTA Evaluation of Reference and Alternative CCMs of CBR Antoing, CBR Lixhe, and ENCI Maastricht

\begin{tabular}{lcccc}
\hline $\mathrm{CCM}$ & Anorg $\mathrm{CO}_{2}$ & $\mathrm{CaCO}_{3}$ & Decarb E & $\begin{array}{c}\text { Decarb E } \\
\mathrm{CaCO}_{3} \text { Der }\end{array}$ \\
\hline Mat & $\begin{array}{c}\text { TGA Meas } \\
\text { (\% by weight) }\end{array}$ & $\begin{array}{c}\text { TGA Der } \\
(\% \text { by weight })\end{array}$ & $\begin{array}{c}\mu \text { Vs/mg } \\
\text { Mat DTA }\end{array}$ & $\begin{array}{c}\mathrm{J} / \mathrm{g} \\
\text { Mat TGA }\end{array}$ \\
CCM/Ant/Ref & 34.0 & 77.3 & 213.4 & 1,378 \\
CCM/Ant/SCP & 33.0 & 75.0 & 172.2 & 1,337 \\
CCM/Ant/Fines & 30.4 & 69.1 & 140.3 & 1,232 \\
CCM/Lxh/Ref & 32.5 & 73.9 & 189.3 & 1,318 \\
CCM/Lxh/SCP & 31.7 & 72.1 & 176.4 & 1,285 \\
CCM/Lxh/Fines & 31.6 & 71.8 & 161.9 & 1,281 \\
CCM/Maa/Ref & 34.2 & 77.7 & 219.3 & 1,385 \\
CCM/Maa/SCP & 32.6 & 74.1 & 181.6 & 1,321 \\
CCM/Maa/Fines & 31.8 & 72.3 & 171.1 & 1,289 \\
\hline
\end{tabular}


Table 10. Mineralogical Analysis by XRD of the Final Reference Clinkers Produced in a Static Kiln

\begin{tabular}{lcccc}
\hline Clinker & Unit & $\mathrm{Cl} / \mathrm{Ant} / \mathrm{Ref}$ & $\mathrm{Cl} / \mathrm{Lxh} / \mathrm{Ref}$ & $\mathrm{Cl} / \mathrm{Maa} / \mathrm{Ref}$ \\
\hline Alite $\left(\mathrm{C}_{3} \mathrm{~S}\right)$ & \% by weight & 64.52 & 65.04 & 71.33 \\
Belite $\left(\mathrm{C}_{2} \mathrm{~S}\right)$ & \% by weight & 19.73 & 14.93 & 8.56 \\
Aluminate $\left(\mathrm{C}_{3} \mathrm{~A}\right)$ & $\%$ by weight & 1.79 & 3.68 & 4.64 \\
Ferrite $\left(\mathrm{C}_{4} \mathrm{AF}\right)$ & $\%$ by weight & 12.86 & 15.87 & 14.89 \\
Free Lime $(\mathrm{CaO})$ & $\%$ by weight & 0.23 & 0.23 & 0.35 \\
Periclase $(\mathrm{MgO})$ & $\%$ by weight & 0.39 & 0.18 & 0.23 \\
Arcanite $\left(\mathrm{K}_{2} \mathrm{SO}_{4}\right)$ & $\%$ by weight & 0.32 & 0.07 & - \\
Aphthitalite & $\%$ by weight & - & - & - \\
\hline
\end{tabular}

different, than those calculated by the Bogue equations, based on the chemical analysis of the final clinkers presented in Tables 12 and 13. The first reason for this deviation is that the DOS factors, although calculated between 80 and 120, did not attaint this goal for the final clinkers of CBR Lixhe and ENCI Maastricht. The reason of this unbalance between alkali and $\mathrm{SO}_{3}$ (\% by weight) is attributable to the different volatility of the $\mathrm{SO}_{3}$ and alkali in a static lab furnace compared to a real clinker kiln, which was explained by Schoon et al. (2012). For both the alternative clinkers of CBR Lixhe and ENCI Maastricht, DOS factors were too low and resulted in lower alite (\% by weight) measured by XRD than that calculated by Bogue (Schoon et al. 2012, 2013a, b, unpublished data, 2014). The lower the DOS factor, the greater the difference between the alite ( $\%$ by weight) measured by XRD and the alite (\% by weight) calculated by Bogue, which was extensively explained by Schoon et al. (2012). The alternative clinker (Cl/Ant/ SCP Fines) partly produced with the fines fraction (Fines/Avg) had a DOS factor slightly higher (136.35) than the DOS limits and a difference of approximately $4 \%$ by weight. Because the high maximization of the fines fraction (Fines/Avg) was approximately $16 \%$ by weight, a higher $\mathrm{SO}_{3}$ (\% by weight) than the original sludge sample (SCP/Avg) was introduced into the alternative CCM. Second, by the increased presence of $\mathrm{MgO}$ ( $2.41 \%$ by weight) (Table 13) introduced by Fines/Avg (Table 7), increased periclase (\% by weight) was measured compared to $\mathrm{Cl} / \mathrm{Ant} /$ reference (Ref) (Table 10) and $\mathrm{Cl} / \mathrm{Ant} / \mathrm{SCP}$ (Table 11), which partly replaces alite Schoon et al. (2013b). Together with the unbalanced DOS factor, this may explain the deviation measured in $\mathrm{Cl} / \mathrm{Ant} /$ Fines. Furthermore, the deviation for the alternative clinkers increases with increased dosage ( $\%$ by weight) of SCP/Avg. As presented in Table 11, higher levels (\% by weight) of SCP/Avg also increase the presence of free lime ( $\%$ by weight), indicating a reduced burnability of the clinker, which was described by Schoon et al. (2013a). Therefore, it can be concluded that the presence of quartz in the $>250 \mu \mathrm{m}$ fraction, as already mentioned, has a negative
Table 12. Chemical Analysis and Bogue Calculations of the Final Reference Clinkers Produced in a Static Kiln

\begin{tabular}{lcccc}
\hline Clinker & Unit & $\mathrm{Cl} / \mathrm{Ant} / \mathrm{Ref}$ & $\mathrm{Cl} / \mathrm{Lxh} / \mathrm{Ref}$ & $\mathrm{Cl} / \mathrm{Maa} / \mathrm{Ref}$ \\
\hline $\mathrm{CaO}$ & \% by weight & 65.90 & 66.28 & 66.18 \\
$\mathrm{SiO}_{2}$ & \% by weight & 22.27 & 21.93 & 21.39 \\
$\mathrm{Al}_{2} \mathrm{O}_{3}$ & \% by weight & 4.14 & 4.40 & 4.54 \\
$\mathrm{Fe}_{2} \mathrm{O}_{3}$ & \% by weight & 3.02 & 4.21 & 3.98 \\
$\mathrm{~K}_{2} \mathrm{O}$ & \% by weight & 0.59 & 0.21 & 0.33 \\
$\mathrm{Na}_{2} \mathrm{O}$ & \% by weight & 0.17 & 0.20 & 0.21 \\
$\mathrm{SO}_{3}$ & \% by weight & 0.89 & 0.12 & 0.36 \\
$\mathrm{MgO}$ & \% by weight & 1.73 & 1.28 & 1.52 \\
$\mathrm{TiO}_{2}$ & \% by weight & 0.25 & 0.30 & 0.30 \\
$\mathrm{P}_{2} \mathrm{O}_{5}$ & \% by weight & 0.21 & 0.24 & 0.17 \\
$\mathrm{Cl}$ & \% by weight & - & - & - \\
$\mathrm{LOI} 975^{\circ} \mathrm{C}\left(\mathrm{O}_{2}\right)$ & \% by weight & 0.48 & 0.39 & 0.48 \\
$\mathrm{DOS} \mathrm{factor}$ & \% by weight & 123.42 & 27.47 & 65.24 \\
$\mathrm{Alite}\left(\mathrm{C}_{3} \mathrm{~S}\right)$ & \% b.84 & 67.52 & 70.61 \\
Belite $\left(\mathrm{C}_{2} \mathrm{~S}\right)$ & \% by weight & 13.44 & 11.95 & 8.07 \\
Aluminate $\left(\mathrm{C}_{3} \mathrm{~A}\right)$ & \% by weight & 5.86 & 4.54 & 5.30 \\
Ferrite $\left(\mathrm{C}_{4} \mathrm{AF}\right)$ & \% by weight & 9.19 & 12.81 & 12.11 \\
\hline
\end{tabular}

effect on the burnability of the clinker. It can be concluded that if sludge of a concrete plant is used as ARM for portland clinker production, low dosages have to be maintained owing to the presence of quartz. A separation phase of $250 \mu \mathrm{m}$ may counter this problem and allow an increased ARM dosage. Nevertheless, the presence of minor constituents as alkali, $\mathrm{SO}_{3}$, and $\mathrm{MgO}$ has to be closely monitored to minimize their negative influences on the portland clinker process.

\section{Further Investigations to Improve the Feasibility of Concrete Sludge As ARM for Portland Clinker}

As was demonstrated in Figs. 1, 2, and 5, there is a clear relationship between $\mathrm{CaO}$ (\% by weight) and $\mathrm{SO}_{3}$ ( $\%$ by weight). This means that if concrete sludge materials can be recovered with the same $\mathrm{SO}_{3}$ (\% by weight), they will have comparable chemical compositions. An investigation will be started to evaluate whether the $\mathrm{SO}_{3}$ (\% by weight) of concrete sludge can be feasibly measured and if the $\mathrm{SO}_{3}$ (\% by weight) of concrete sludge follows a trend in time by which it increases, decreases, or is randomly dispersed. When a clear trend is noticeable, the recovery of the concrete sludge may be individually managed for each concrete plant based on the $\mathrm{SO}_{3}$ (\% by weight), by which a decrease in the chemical variation of the concrete sludge could be possible. Further investigation should demonstrate whether this decrease in chemical variation would be sufficient, together with the findings in the previous sections, to make the sludge acceptable as a valid ARM for portland clinker production.

Table 11. Mineralogical Analysis by XRD of the Final Alternative Clinkers Produced in a Static Kiln

\begin{tabular}{|c|c|c|c|c|c|c|c|}
\hline Clinker & Unit & $\mathrm{Cl} / \mathrm{Ant} / \mathrm{SCP}$ & $\mathrm{Cl} /$ Ant/Fines & $\mathrm{Cl} / \mathrm{Lxh} / \mathrm{SCP}$ & $\mathrm{Cl} / \mathrm{Lxh} / \mathrm{SCP}$ Fines & $\mathrm{Cl} / \mathrm{Maa} / \mathrm{SCP}$ & $\mathrm{Cl} / \mathrm{Maa} /$ Fines \\
\hline Alite $\left(\mathrm{C}_{3} \mathrm{~S}\right)$ & $\%$ by weight & 65.37 & 56.88 & 61.54 & 51.99 & 61.86 & 60.86 \\
\hline Belite $\left(\mathrm{C}_{2} \mathrm{~S}\right)$ & $\%$ by weight & 20.32 & 27.56 & 20.69 & 29.06 & 19.53 & 19.36 \\
\hline Aluminate $\left(\mathrm{C}_{3} \mathrm{~A}\right)$ & $\%$ by weight & 1.84 & 3.78 & 2.30 & 2.03 & 2.61 & 3.15 \\
\hline Ferrite $\left(\mathrm{C}_{4} \mathrm{AF}\right)$ & $\%$ by weight & 12.00 & 10.42 & 14.59 & 16.03 & 14.18 & 15.66 \\
\hline Free lime $(\mathrm{CaO})$ & $\%$ by weight & 0.06 & 0.04 & 0.25 & 0.09 & 0.85 & 0.09 \\
\hline Periclase $(\mathrm{MgO})$ & $\%$ by weight & 0.36 & 1.08 & 0.48 & 0.40 & 0.50 & 0.50 \\
\hline Arcanite $\left(\mathrm{K}_{2} \mathrm{SO}_{4}\right)$ & $\%$ by weight & - & - & - & 0.02 & - & 0.05 \\
\hline Aphthitalite & $\%$ by weight & - & 0.09 & - & 0.13 & 0.05 & 0.08 \\
\hline Anhydrite & $\%$ by weight & - & - & - & - & 0.12 & 0.02 \\
\hline Portlandite & $\%$ by weight & 0.06 & 0.12 & 0.03 & 0.24 & 0.31 & 0.22 \\
\hline
\end{tabular}


Table 13. Chemical Analysis and Bogue Calculations of the Final Alternative Clinkers Produced in a Static Kiln

\begin{tabular}{|c|c|c|c|c|c|c|c|}
\hline Clinker & Unit & $\mathrm{Cl} / \mathrm{Ant} / \mathrm{SCP}$ & $\mathrm{Cl} /$ Ant/Fines & $\mathrm{Cl} / \mathrm{Lxh} / \mathrm{SCP}$ & $\mathrm{Cl} / \mathrm{Lxh} /$ Fines & $\mathrm{Cl} / \mathrm{Maa} / \mathrm{SCP}$ & $\mathrm{Cl} / \mathrm{Maa} /$ Fines \\
\hline $\mathrm{CaO}$ & $\%$ by weight & 66.30 & 65.33 & 66.08 & 65.58 & 66.64 & 65.98 \\
\hline $\mathrm{SiO}_{2}$ & $\%$ by weight & 22.60 & 22.58 & 22.29 & 22.82 & 22.12 & 22.20 \\
\hline $\mathrm{Al}_{2} \mathrm{O}_{3}$ & $\%$ by weight & 4.04 & 4.40 & 4.13 & 4.45 & 4.11 & 4.50 \\
\hline $\mathrm{Fe}_{2} \mathrm{O}_{3}$ & $\%$ by weight & 2.92 & 2.86 & 3.87 & 3.70 & 3.53 & 3.66 \\
\hline $\mathrm{K}_{2} \mathrm{O}$ & $\%$ by weight & 0.36 & 0.30 & 0.21 & 0.12 & 0.22 & 0.23 \\
\hline $\mathrm{Na}_{2} \mathrm{O}$ & $\%$ by weight & 0.17 & 0.20 & 0.18 & 0.15 & 0.19 & 0.21 \\
\hline $\mathrm{SO}_{3}$ & $\%$ by weight & 0.57 & 0.70 & 0.24 & 0.17 & 0.21 & 0.20 \\
\hline $\mathrm{MgO}$ & $\%$ by weight & 1.79 & 2.41 & 1.65 & 1.71 & 1.77 & 1.81 \\
\hline $\mathrm{TiO}_{2}$ & $\%$ by weight & 0.26 & 0.29 & 0.29 & 0.29 & 0.26 & 0.29 \\
\hline $\mathrm{P}_{2} \mathrm{O}_{5}$ & $\%$ by weight & 0.20 & 0.21 & 0.23 & 0.23 & 0.19 & 0.17 \\
\hline $\mathrm{Cl}$ & $\%$ by weight & N/A & 0.03 & N/A & N/A & N/A & N/A \\
\hline LOI $975^{\circ} \mathrm{C}\left(\mathrm{O}_{2}\right)$ & $\%$ by weight & 0.34 & 0.33 & 0.40 & 0.38 & 0.35 & 0.31 \\
\hline DOS factor & - & 108.44 & 136.35 & 58.39 & 57.48 & 48.56 & 42.85 \\
\hline Alite $\left(\mathrm{C}_{3} \mathrm{~S}\right)$ & $\%$ by weight & 66.77 & 60.65 & 66.27 & 58.30 & 70.47 & 64.36 \\
\hline Belite $\left(\mathrm{C}_{2} \mathrm{~S}\right)$ & $\%$ by weight & 14.43 & 18.00 & 13.92 & 21.45 & 10.27 & 15.10 \\
\hline Aluminate $\left(\mathrm{C}_{3} \mathrm{~A}\right)$ & $\%$ by weight & 5.77 & 6.82 & 4.40 & 5.53 & 4.92 & 5.73 \\
\hline Ferrite $\left(\mathrm{C}_{4} \mathrm{AF}\right)$ & $\%$ by weight & 8.89 & 8.70 & 11.78 & 11.26 & 10.74 & 11.14 \\
\hline
\end{tabular}

\section{Conclusions}

A large chemical variation between different concrete sludge samples was noted, which only marginally decreased when the concrete sludge samples were collected individually for each concrete plant. No clear influence of the seasons was observed in the chemical composition of the sludge samples. The chemical variation of concrete sludge is too large to be used as a valid ARM in portland clinker production. It was also shown that the sludge from the water treatment system of concrete plants specifically collects the finer fractions of the various raw materials of the concrete, because of which the cement content in the sludge samples is much higher than in normal recycled concrete. Because of this difference, promising techniques for creating an ARM out of recycled concrete were not successful for concrete sludge. A separated fines fraction of $250 \mu \mathrm{m}$ does not have improved chemical composition or variation, but has improved burnability within the alternative portland clinker. Furthermore, the higher concentration of cement stone derivatives present in the fines fraction improves the potential to reduce the inorganic $\mathrm{CO}_{2}$ emission.

Nevertheless, a fraction larger than $250 \mu \mathrm{m}$ shows no improved suitability for concrete applications because of the presence of high levels of cement derivatives, as was the case for recycled concrete crushed and separated with the same technique.

The presence and variation in concentration of minor constituents, such as alkali, $\mathrm{SO}_{3}$, and $\mathrm{MgO}$, act as a second limit on the maximization of both sludge samples and their fractions of specific fines.

The possible energy gain from the lowered decarbonation energy attributable to a decreased limestone dosage is negligible because of the energy required for the liberating the chemically bound water. The only positive effect on the ecological impact of portland clinker production is that a primary natural material may be replaced by a secondary recycled material.

After this study, it can be concluded that sludge out of concrete plants cannot be classified as a feasible alternative raw material for portland clinker production owing to the cited restrictions.

\section{Acknowledgments}

The authors wish to thank the Central lab of Sagrex Quenast and the cement research lab of ENCI Maastricht for their support, Dr. Els Bruneel for her aid during TGA analysis, Jo Lejeune for his help during the XRD tests and the staff of the concerned concrete plants for their efforts during the collection of the 87 concrete sludge samples.

\section{References}

CEN (European Committee for Standardization). (2000a). "CementPart 1: Composition, specifications and conformity criteria for common cements." EN 197-1, Brussels, Belgium.

CEN (European Committee for Standardization). (2000b). "CementPart 2: Conformity evaluation." EN 197-2, Brussels, Belgium.

CEN (European Committee for Standardization). (2000c). "CementPart 3: Determination of setting times and soundness." EN 196-3, Brussels, Belgium.

Chatveera, B., and Lertwattanaruk, P. (2009). "Use of ready-mixed concrete plant sludge water in concrete containing an additive or admixture." J. Environ. Manage., 90(5), 1901-1908.

Chatveera, B., Lertwattanaruk, P., and Makul, N. (2006). "Effect of sludge water from ready-mixed concrete plant on properties and durability of concrete." Cem. Concr. Compos., 28(5), 441-450.

Christensen, N. H. (1979). "Burnability of cement raw mixes at $1400^{\circ} \mathrm{C}$ : The effect of the fineness." Cem. Concr. Res., 9(3), 285-294.

Ghosh, S. N. (1991). "Progress in cement and concrete: Part 1." Burnability and clinkerization of cement raw mixes, Vol 1, Thomas Telford, London.

Hewlett, P. (1988). Lea's chemistry of cement and concrete, 4th Ed., Elsevier, Amsterdam, Netherlands, 1057.

Kakali, G., and Tsivilis, S. (1993). "The effect of intergrinding and separate grinding of cement raw mix on the burning process." Cem. Concr. Res., 23(3), 651-662.

Lin, K. L., Chiang, K. Y., and Lin, C. Y. (2005). "Hydration characteristics of waste sludge ash that is reused in eco-cement clinkers." Cem. Concr. Res., 35(6), 1074-1081.

Lin, K. L., and Lin, C. (2005). "Hydration characteristics of waste sludge ash utilized as raw cement material." Cem. Concr. Res., 35(10), 1999-2007.

NBN (Bureau of Normalization). (2000). "Tests for mechanical and physical properties of aggregates. Part 6: Determination of particle density and water absorption." NBN EN 1097-6, Brussels, Belgium.

NBN (Bureau of Normalization). (2002). "Mixing water for concreteSpecification for sampling, testing and assessing the suitability of water, including water recovered from processes in the concrete industry, as mixing water for concrete." NBN EN 1008, Brussels, Belgium.

Ökopol GmbH, Sander, K., Schilling, S., and Lüskow, H. (2008). "Review of the European list of waste." Ökopol Institut für Ökologie und Politik, Hamburg, Germany. 
Sales, A., Rodrigues de Souza, F., and do Couto Rosa Almeida, F. (2011). "Mechanical properties of concrete produced with a composite of water treatment sludge and sawdust." Constr. Build. Mater., 25(6), 2793-2798.

Schoon, J., De Buysser, K., Van Driessche, I., and De Belie, N. (2013a). "Feasibility study on the use of cellular concrete as alternative raw material for portland clinker production." Constr. Build. Mater., 48, 725-733.

Schoon, J., Van der Heyden, L., Eloy, P., Gaigneux, E. M., De Buysser, K., Van Driessche, I., and De Belie, N. (2012). "Waste fibrecement: An interesting alternative raw material for a sustainable portland clinker production." Constr. Build. Mater., 36, 391-403.
Schoon, J., Vergari, A., De Buysser, K., Van Driessche, I., and De Belie, N. (2013b). "Fines extracted from porphyry and dolomitic limestone aggregates production: $\mathrm{MgO}$ as fluxing agent for a sustainable portland clinker production." Constr. Build. Mater., 43, 511-522.

Tay, J. (1989). "Reclamation of wastewater and sludge for concrete making." Resour. Conserv. Recycl., 2(3), 211-227.

Taylor, H. F. W. (1997). Cement chemistry, 2nd Ed., Thomas Telford, London, 459.

TOPAS [Computer software]. Madison, WI, Bruker.

Tsamatsoulis, D. (1979). "Modeling of raw materials blending in raw meal grinding systems." Latest trends on systems, N. E. Mastorakis, V. Mladenov, and Z. Bojkovic, eds., Vol. 1, 129-134. 